\title{
Russia in world society: A comparative perspective on international references in parliamentary debates
}

\section{Tatiana Tiaynen-Qadir}

(School of Humanities,) University of Eastern Finland, Finland

\section{Ali Qadir}

(New Social Research Program,) University of Tampere, Finland

\section{Pertti Alasuutari}

(Faculty of Social Sciences,) University of Tampere, Finland

\section{Corresponding author}

Dr. Tatiana Tiaynen-Qadir, Yliopistonkatu 4, Agora, Joensuu 80101, Finland.

Email: tatiana.tiaynen@live.fi

\section{Abstract}

This article explores how international references in parliaments build a synchronized world polity, even in countries that are often portrayed as being at odds with the rest of the world. The article asks whether and how Russian parliamentarians refer to the international community, and how such references compare with parliamentary debates in other countries. The “mesophenomenological” argument developed here connects World Society Theory, which demonstrates global isomorphism, with national studies of Russia, which argue for important national particularities. The empirical analysis draws on a stratified random sample of debates on draft laws in the Russian Duma from 1994 to 2013, comparable to similar samples from six other countries. The results show that 1) Russian parliamentarians refer to the international community in the same level and the same forms as in other countries; 2) Russian 
policymakers rely on the same imageries of the social world to convince their audiences as do other parliamentarians; and 3) this similarity in form remains consistent throughout the period, despite radical changes in national politics. These findings attest to the Russian Duma as a site of world culture, and to the mesophenomenological view that the world polity is highly synchronized through discourses of cross-national comparisons.

\section{Keywords}

Russia, world culture, World Society Theory, transnational sociology, synchronization, imageries, international references, parliament, discourse analysis

\section{Acknowledgements}

The authors wish to acknowledge members of the Tampere research group for Cultural \& Political Sociology for research assistance and for comments on earlier versions. Thanks are also due to three anonymous reviewers and the editorial team at Acta Sociologica, all of whom provided insightful and detailed comments. Tatiana Tiaynen-Qadir's research for this article was supported by the Academy of Finland research project "Epistemic governance in policymaking” (SA 276076, Pertti Alasuutari PI). Ali Qadir’s research was supported by the Academy of Finland research project “Morality in politics” (SA296045, Ali Qadir PI). Pertti Alasuutari's research was supported by the Academy of Finland Professorship (1 Jan 2016 to 31 Dec 2020). 


\section{Introduction}

Significant scholarship in World Society Theory (WST) has convincingly illustrated how deeply the idea of a nation-state has been naturalized as an organizing principle of world society, and how strikingly isomorphic nation-state institutions, structures and world culture principles are (Bradley and Ramirez, 1996; Meyer et al., 1997). Such ideas as modernization, progress, and evolution are deeply rooted in modern world society, and have become almost universally assumed world cultural principles (Qadir, 2016: 141). Since the seminal article by Meyer at al. (1997) a great deal of empirical research has been conducted to validate this isomorphism around the world. Yet, the mile-high view of isomorphism tends to hide from view the field struggles that take place during policy formulation within each country. Building from the same neoinstitutionalist perspective, recent theorizing has complemented WST with bottom-up approaches that scrutinize how global isomorphism emerges as an outcome of discursively “synchronized” decision-making and national parliamentary battlefields (Alasuutari, 2016; Alasuutari and Qadir, 2014b; see also Qadir, 2016).

In all such institutionalist accounts of decision-making, whether from the top down or from the bottom up, the focus has inevitably been on Western-style democracies (although, see Hedin, 2016: for a case of reverse diffusion of labor policy models during ILO negotiations in the Cold War). Our aim in this paper is to test whether a state as different from such democracies as the Russian Federation—and indeed one that has long been a discursive Other of such democracies—also fits into the neoinstitutionalist framing of worldwide synchronization. If it does, that makes the case much stronger for investigating a truly globe-spanning, synchronized world society. If it doesn't, then WST and similar theorizing have to account for this difference by, for instance, discussing two alternative world societies (and, then, perhaps more). 
This question becomes significant when we consider the huge scholarly literature on Russia in the world. Historical, sociological, anthropological, and International Relations research on Russia is, by now, almost too voluminous to survey. Yet, much of it centers on how Russia has been historically and culturally distinct from Western Europe and USA, although to some extent dependent in its norms and values (for some variations, see Kotkin, 2001; Lyytikäinen, 2016; Morozov, 2013; Neumann, 2008; Sakwa, 2008; Salmenniemi, 2008; Stivachtis, 2015; Tsygankov and Tsygankov, 2007). Some studies have concluded that, since Peter the Great, Russia has shown a desire to become "Western” or “civilized,” but that Western-style democratic values are "lagging" or could not take root because of tremendous political cultural differences, and that Russia never managed to consolidate into a viable global alternative (e.g. Morozov, 2013; Neumann, 2008; Sakwa, 2008; Stivachtis, 2015). Other research points out the problems in expecting similar political cultural evolution due to the legacy of socialism(s) (e.g. Burawoy and Verdery, 1999; Hann et al., 2002; Humphrey, 2002; Kotkin, 2001; Rogers, 2010; Tsygankov, 2015; Whitefield, 2005).

Such studies into micro-level political discourse in Russia are revealing, and shed nuanced light on the cultural specificities of the Russian context or else how the political culture of the country has evolved in tension with the Atlantic world. Yet, both sets of metanarratives zoom in on the specificities of Russian political culture and differences between Russia and Western Europe. As a result, much of this research brushes aside the fact that Russia is after all a nation-state, organized as most other states are. It has comparable decision-making structures, comparable political divisions, and comparable political rhetoric. The similarity in form of Russian political structures with other democratic countries may seem obvious, but it has great implications once those forms are examined in detail. This doesn’t negate research that might justifiably identify Russian political culture as different from, say, the USA. But by focusing on forms of political arrangements and discourses we 
can get at a better understanding of whether and to what extent Russia is genuinely a member of the world society. Our argument is hence aimed at contributing to World Society Theory and global isomorphism—by offering a discursive bridge to micro-cultural political analyses_ - and by adding the intriguing case of Russia, which has largely been ignored.

Our approach juxtaposes micro-level political cultural analyses with the macro-level view of isomorphism in WST. In that sense, we are working at a conceptual meso-level of analysis that fits between undeniable global isomorphism on one hand and undeniable microcultural specificity on the other. In order to do so, we analyze a pre-eminent site of world political culture: the parliament. We draw on a stratified random sample of debates on draft laws that have taken place in the Russian Gosudarstvennaya Duma (hereafter Duma) between 1994 and 2013, comparable to similar samples gathered from six other countries: Australia, Canada, Trinidad and Tobago, Uganda, the United Kingdom, and the United States. Earlier research based on the data set from these six countries shows that roughly $80 \%$ of debates include references to the international community (Alasuutari, 2014), with interesting features regarding the USA and Russia that we discuss below. It also illustrated that policymakers evoke rather similar world cultural principles or imageries of the social reality in their political rhetoric.

In this respect it is interesting to study how the debates in Russian Duma differ from or are similar to those of other countries, and whether the Russian parliamentarians appeal to the world culture principles in their rhetorical strategies. Hence the questions addressed in this article are: do Russian parliamentarians appeal to other countries’ policies and experiences, as well as to the international framework in general in their justifications for or against a certain bill or policy, just as parliamentarians in Western countries do? Are the rationales and justifications by which these references are made and decisions are defended considerably different from those employed in other countries? Does the nature of such 
references considerably change over the given period of time? The last is especially important in the light of micro-level political culture analyses of Russia, where a general conclusion is that Vladimir Putin significantly impacted Russian relations since he first became President in 2000. Based on such literature, it might well be hypothesized that Russia's radically divergent political culture will lead to (1) few references to the international community when justifying national laws, (2) justification discourse of a significantly different nature than in Western democracies, and (3) marked differences in such discourses before and after Putin's rise. We test these hypotheses below.

The rest of this article is organized in the following way. In the next section we discuss in more detail the theoretical framework, followed by a section detailing the data and methodology of this study. The next three sections report on the results of the empirical analysis, one section on interdependent decision making through the brief cross-national analysis of the debates in seven countries, and two other sections, focusing on the two worldwide imageries — progress and competition — that the Russian parliamentarians turn to in their justifications. Throughout the results, we highlight the periods 1994 to 2003, before Putin had a significant impact, and 2004 to 2013, the period of regime consolidation and then “developed Putinism” (Sakwa, 2013). The distinction is relevant since commentators have noted that it involves weak democratic institutions, for instance in pre-selecting party candidates for parliamentary elections. So, if justifications in this period still resemble those of other countries, a strong case can be made for Russia being a part of political world culture. In the final section we draw empirical and theoretical conclusions from the results.

\section{Synchronization of national policies and imageries of social reality}

According to the classical English School of International Relations, the Soviet Union and its allies, on one side, and the West, on the other, formed two sub-global international systems 
that operated within the framework of a single yet thin and very heterogeneous global international society (Watson, 1992: 290). According to this tradition, after the collapse of the Soviet Union, Russia sought to join international society governed by norms of Western states to meet the standard of “civilization" (Stivachtis, 2015). We suggest that rather than focusing on the differences between these two international systems, we may also adopt the WST perspective and conceive of the Soviet Union as one actor in the single world society. It can be argued that despite peculiarities (which exist in every part of the world), Russia is already part of the same world society and world culture as the rest of the world (Meyer et al., 2009). Its membership in the international community did not begin only after the Soviet collapse, but during and even before the Soviet era.

Consider the very creation of the Soviet Union and its state-controlled economic policy from the 1930s on: as Karl Polanyi points out, parallel to Great Britain abandoning the gold standard, the USA launching the New Deal, and the National Socialist Revolution in Germany, the Soviet planned economy was just another version of the worldwide response to the crises of market liberalism that had dominated economic policy in Europe and America from the early $19^{\text {th }}$ century (Polanyi, 1957). Similarly, Perestroika (translated from Russian as "rebuilding") — the radical reorganization of the Soviet political and economic policy that eventually triggered the dissolution of the Soviet Union (Kotkin, 2001)—can be also seen as one of the manifestations of the global swing of the pendulum from more state-controlled policies to neoliberalism that spread across the globe from the 1970s onward. Liberalization of the Chinese communist-rule economy in the end of 1970s, Thatcherism in Britain, and Ronald Reagan's deregulating economy policy in the USA in the 1980s, are other examples of this global policy fashion (Harvey, 2005).

Neoinstitutionalist world society theory stresses that the contemporary world cannot be understood without acknowledging the existence of world culture, rooted in the 
institutional infrastructure of world society (Meyer et al., 1997, 2009; Thomas, 2009). Accordingly, world society theorists have pointed out that there is outstanding conformity of principles in the world (for instance in human rights, environmentalism, education, and so on) and have amassed considerable evidence of structural isomorphism of nation-states in the face of enormous differences in resources and traditions. Much of this builds on the revelation that the nation-state is an "imagined," constructed community (Anderson, 1991). In a broad historical perspective, the idea of nation-state is a "world cultural script" (Meyer et al., 1997) of how to organize a society that all countries have adopted over the past couple of hundred years, including Russia. The script draws its legitimacy from the fact that others have done the same, and such similarity in form leads to imbibing certain principles such as that of national uniqueness, national progress, and the cult of individual agency (Meyer, 2010). WST scholars refer to this as a "macrophenomenological" perspective as opposed to the microphenomenological perspective that prioritizes explanations by way of "national cultural and interpretive systems” (Meyer et al., 1997: 147). Differences in the way world models are enacted in local contexts are accounted for by the notion of decoupling or loose coupling: actors hypocritically enact world models but ignore or fail to implement them in practice (e.g. Bromley and Powell, 2012).

We find this neoinstitutionalist evidence and argument compelling in general, and a useful way to move past the rigid barriers created by an academic master narrative of seemingly monolithic camps of the "West" and Russia. Yet, since in this study we approach interdependent decision making from the perspective of local actors and how they employ international comparisons and world-cultural ideas, some re-conceptualizing is needed. For instance, treating the Soviet system as one manifestation of the era of more state-centered economic policies cannot be properly grasped by the concept of decoupling. Although built 
on the same ideals as a response to the ills of market liberalism, socialism was a certain manifestation of such ideals, but not a result of a failure to enact a world model. ${ }^{1}$

The same goes for postsocialist transformation: it is not analytically useful to treat the fact that Russia still differs considerably from many liberal democracies as proof of decoupling from “original” models. Instead of conceptualizing interdependent decisionmaking as diffusion of world models, it is better to approach it as synchronization of national policies (Alasuutari, 2016). It is a constant process in which policymakers in a given country are influenced by and appeal to world-cultural ideals and trends. Our argument ties in with calls to "decolonize" postsocialist studies that often begin with "the assumption that socialism and capitalism are mutually exclusive formations, and in viewing the apparently one-way traffic of neoliberalism from West to East” (Kangas and Salmenniemi, 2016: 221; see also Bockman, 2007). Indeed, the same perspective of neoliberal diffusion from the West is often assumed in WST accounts of isomorphism.

Synchronization does not mean that national states become increasingly similar to each other, but that the parliamentary culture of conduct is quite similar everywhere in its form. Thus, our interest is not in the causal connections and actual policies that are implemented, but in the parliamentary site as an isomorphic structure that presupposes similar forms of justifications and reveals interdependent decision-making in all countries. References to the international framework and other countries are so obvious in all parliaments that the interdependence it implies often goes unnoticed in functionalist approaches, but it is actually what facilitates synchronization of national policies.

Parliamentarians (and other policymakers) seek to affect social change through convincing others of a particular reading of the situation and the "natural" solution to this situation. Earlier research that focused on parliamentary debates in a WST perspective illustrated that in this process of persuasion, irrespective of the specific features of various 
national contexts, parliamentarians activate similar world cultural principles (Alasuutari, 2016: 94-115). In this process, they wittingly and unwitting rely on others’ perception of the world and then work upon it. Such process is referred to here as epistemic governance, extending the Foucauldian analysis to policymaking (Alasuutari and Qadir, 2014a).

These world cultural principles comprise two "imageries of social reality" (Alasuutari and Qadir, 2016)—progress and competition—which prominently figure in parliamentarian debates in other countries. ${ }^{2}$ Our analysis below illustrates that these imageries also underpin argumentation in the Russian duma. These imageries of social reality are naturalized lenses of perceiving the social world: they have congealed into an appearance of self-evident assumptions that govern people’s perception of social reality. They are built on "root metaphors” by which we all think of society (Brown, 1989), but articulated with a policy goal. An imagery’s self-evidence lures parliamentarians to view and present the situation in a certain way and conceals alternative visions. The term imagery enables us to articulate spontaneous, unconscious, and not necessarily rationally apprehended aspects of these governing assumptions and beliefs in national policymaking in the parliaments. It is through these imageries that epistemic governance functions on the naturalized ways of conceiving reality.

\section{Data and methodology}

The primary data we examine are 120 debates on new laws in the Russian Duma from 1994 to 2013. The debates are roughly evenly spread over the ten policy areas of civic policy, consumption, crime, education, fiscal policy, foreign and security policy, health, science and technology policy, and social policy. The sampling technique applied to this parliamentary debates dataset can be characterized as stratified random sampling: the cases selected are divided as evenly as possible between the 20 years and the ten policy sectors. 
In addition to the Russian parliamentary debates, the data analyzed here comprise "second readings" of bills or "draft laws” from six countries: Australia, Canada, Trinidad and Tobago, Uganda, the United Kingdom, and the United States. These six countries were selected for the substantial variation in their economy, level of technological development, and institutionalization of democracy. What is called a "second reading" in several countries is the introduction and debate on a proposal for a new law or revision to an existing law. (The Russian data include sets of three readings of each bill, as in the Russian Duma the discussions take place at all stages of the consideration of the bill.) From each country, a sample of 120 bills was collected. This online, public domain resource is an excellent window into political talk in parliaments worldwide. In all seven countries, the database is available online from the parliamentary websites and can be searched in multiple ways. The data here were collected using search functions, although all texts were also read.

Within the data we searched for references to other countries and the international community by speakers justifying or opposing a new bill. We differentiate six different ways in which references to other countries are explicitly used as a mode of justification that we find generally in parliamentary talk around the world (Alasuutari, 2014). These are international comparison, international standards or recommendations, international treaties or laws, exogenous policy models, models considered as something that other countries should adopt, and the nation's reputation or international image. The occurrence of each type of references was coded as a dummy variable.

The Russian data were coded by one of the authors for whom Russian is a mother tongue and who has been working with discourse analysis of a variety of Russian-language qualitative data. The data here are part of a larger database on similar debates collected from 14 countries by a team of researchers. Tests of inter-coder reliability on international 
references (a random 5\% of all debates were coded by all researchers) resulted in an agreement level of over $90 \%$.

The choice to use parliamentary debates as a window to national policymaking was based on the conviction that they constitute one interface through which global ideas about desirable policies become integrated with national policy discourses, thereby contributing to synchronization of national policies. This said, we do not mean that floor debates are a oneto-one reflection of national policies. For instance, parliaments may be rubber stamps for decisions already taken within a power elite. Yet it is noteworthy that even many dictatorships have parliaments. This shows that the idea of democratic, deliberative decisionmaking, embodied in the national parliament, is a widely-acknowledged world-cultural principle to which even autocratic regimes pay (insincere) respect by "putting on a show." The significance of floor debates is due to their function as a public forum in which politicians justify their views in morally acceptable and convincing ways. From that perspective they are ideal, naturally occurring research material by which to study how policymakers try to convince the majority about what is the right and sensible decision to take. Participants in the debates are well aware that their justifications and argumentations are not only intended for other parliamentarians: the audience is the public beyond the parliament's walls. Parliamentarians are conscious of speaking not just to their colleagues, but to their parties, constituents and other stakeholders, the national public, and even the worldwide community, all of whom are mediated audiences (Fairclough and Fairclough, 2013). We are not interested here in whether the bill goes through or gets rejected, what its political context might be, or whether it brings about any change in the society. Rather, our attention is on whether and how references to the international community are utilized by the parliamentarians in their rhetorical strategies. 
We placed Russia in comparison with other countries primarily to put forward the evidence that such references structure parliamentary talks in all seven countries, irrespective of their cultural specificities. In-depth analysis of the Russian discussions was conducted to identify the patterns of making such references, in which we apply a range of methods from discursive (Fairclough, 2003; Potter, 1996; Wood and Kroger, 2000) to rhetorical analysis (Billig, 1996; Perelman, 1982). In particular, we looked closely at the talk surrounding international references, the mode of justification, which countries are referred to, and how these references are made, positively, negatively, ironically etc. We are not getting at some new, or alternative, truth to Russian political culture, but at certain patterns of talk in Russian parliamentary discourse. In the following, we bring in quotations to illustrate the analytical point being made, not to prove it but rather to exemplify the variations in these categories.

\section{References to the international community: Similarities in form}

When we take a look at parliamentary debates in a cross-national perspective, it is striking how alike they are. The modes of justification and figures of speech are very similar. In this sense we are at the very core of world culture, institutionalized in the system of regional states, each of which contain similar assemblies. To advance the argument that a proposed law is good for the country, speakers need to convince the audience of the existence, scope and gravity of a problem or a need for change. Secondly, they need to convince others of the rationality, efficiency and moral adequacy of the proposed solution. In all these instances, speakers may evoke the international community within which national decision-making takes place. This is not always done explicitly, yet open references to what is going on outside the national borders are also common.

Figure 1 shows that parliamentarians in all seven countries, including in Russia, refer to the international community, and all the mentioned six different ways of making such 
references are utilized. Thus, such references are a common feature of the parliamentarian talks in all seven countries, which signifies their similarity in form, although the frequency of such references may vary from country to country.

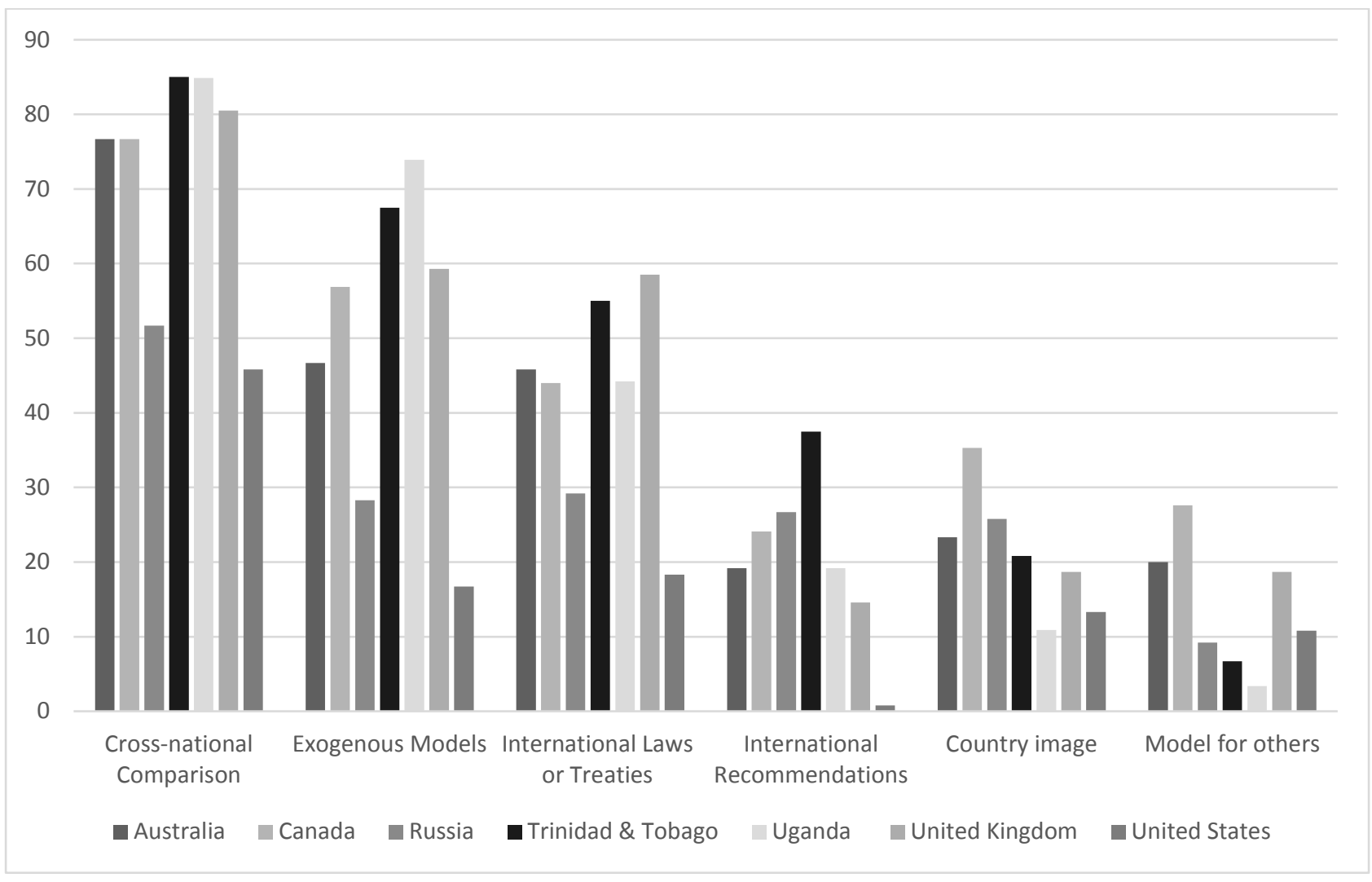

Figure 1. References to the international community

References to international recommendations often comprise a reference to an intergovernmental or other international organization that has issued a recommendation or promoted a "best practice." This discourse is prevalent in the Duma as well. Speakers also commonly refer to intergovernmental organizations or they just mention that international recommendations have been taken into account, even though no particular recommendation or its international source is mentioned.

In other categories such as cross-national comparisons, exogenous model, international treaties and model for others, Russia is rather similar to the U.S. As Figure 1 
shows, while one can find international comparison in over three fourths of debates in the other countries, in Duma and the U.S. Congress they can be found in half of debates.

However, although Russia and the United States are somewhat distant from other countries in these categories, the frequency is still quite substantial. In this sense, we can say that Russia (like the U.S.) is not a unique or exceptional case when it comes to the ways legislation is debated in the national parliament. Comparative data such as in Figure 1 easily draws attention to numbers and percentages that points to differences, but it is important to bear in mind that the discourses are the same, part of world culture, even if frequencies in their use vary from country to country. Even in the types of international references that are less frequent, Duma discussions do not really stand out from the other countries. The investigation also shows that parliamentarians in the Russian Duma commonly debate new legislation by alluding to what is going on in other countries or by referring to international recommendations.

The finding that in some respects Russia is close to the USA as a country in which laws are not as frequently justified by referring to other countries, is certainly interesting. It does not prove, however, that the United States and Russia are isolated from the rest of the world, but it may be due to the political cultures of these countries. Politicians typically compare their country to others that are in the same "league:” its reference group or those considered its competitors. As an economic and military world power, in many respects the United States does not have a match in the world (Trichur, 2005), which is why comparisons and league tables are less often used in political rhetoric. A similar thing could be said about Russia as a former superpower. Also, the federation structure of both states may encourage internal cross-references between different states in the U.S. congress and various federal subjects in the Russian Duma. 
Another explanation is that both countries share a strong belief in their unique, divine roles in the human history. In the U.S., American exceptionalism signified the belief that America is historically unique, even divinely inspired, in its superiority in the world. In Russia, old traditionalists commonly referred to as Slavophiles advocated the idea of its divine fate in human history. Both countries thus share this discursive strategy in highlighting their national histories and unique paths, and thereby still follow the world culture script of a nation-state.

From our mesophenomenological viewpoint, it is important that the patterns of talk are so very similar. Not only do Russian parliamentarians make constant and comparable frequency of references to the international community, but they also do so in the same ways. We find no additional category of references in Russia that does not exist elsewhere, nor do we find a common strategy elsewhere that is missing in the Russian Duma debates.

Another important finding is that the frequency of references to the international community remains more or less the same throughout the entire period. Figure 2 illustrates how Russian parliamentarians activate cross-national comparisons, "model for others” and “country image” justifications, as well as references to exogenous model, international treaties and recommendations as frequent in the period between 1993 and 2003 as in the period between 2004-2013. This consistency may be considered as surprising given that significant political changes took place during the 20 years’ span. The common understanding in research is that starting from Putin's presidency in 2000 there has been a shift toward a more authoritarian and direct rule (Neumann, 2008), a period of "regime consolidation” from 2003 to 2008, that eventually led to “developed Putinism” in 2012 (Sakwa, 2013). 


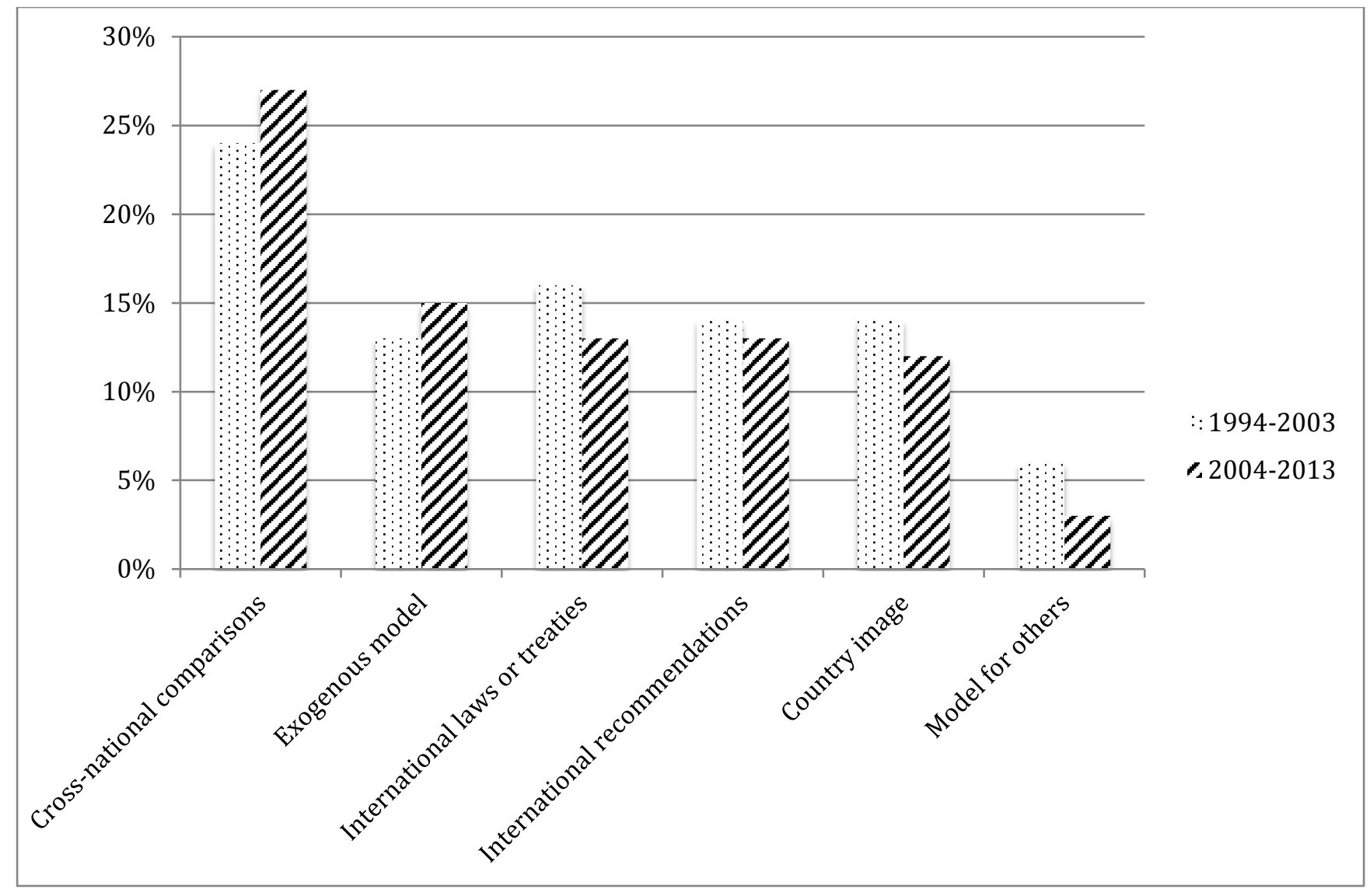

Figure 2. References in the Russian Duma in the periods 1993-2003 and 2004-2013

It could have been assumed that Putin's rule, which sharpened opposition to Western countries, would also result in lower frequency in references to the international community. Yet as Figure 2 illustrates these local political changes (that are undoubtedly important to the content of policies) did not significantly affect the form of parliamentarian talk. That talk is at the mesophenomennological level, connecting the macrophenomenological world culture of isomorphism to microphenomenological political culture and systems of interpretation.

\section{"Upward and onward": The imagery of progress}

References to the international community can sometimes be a means to boost national pride by arguing that in the policy area in question the country is known for being at the cutting 
edge of development, creating a policy that other countries will also adopt. However, in the majority of cases speakers invoke the issue in question in an international perspective to argue that there is a problem or deficiency in the way things have been organized nationally thus far. Speakers argue that "we” do poorly in comparison with some other countries, and that we should learn from models adopted in better performing states.

This rhetorical strategy is also common in the Russian Duma. Western countries are predominantly referred to positively or as exogenous models that Russia should follow:

Oil-producing industry is a far too tricky sector. Dirty and tricky. You know how many debates about oil we have had over the past two years, when we let everything go and be. You know what role oil plays in all oilproducing regions of the world. And there is special legislation for that everywhere. The oil produced and transported in Norway is protected by state laws of Norway from all sides. We have been there, and studied this question (Duma, “Oil and gas,” May 27, 1994:

http://transcript.duma.gov.ru/node/332641/).

To convince the audience and add more weight to their arguments, Russian policymakers refer to experiences of the "most developed countries," the "civilized countries of the world," the "world community," and "the whole world.” All these expressions largely signify “developed countries” (USA, Canada, Australia, Germany, France, Austria, Nordic countries, and others) which are portrayed as more advanced in their financial, economic and consumer policies. These countries are usually referred to as examples of "normal international practice” or simply as "normal developed countries.” Correspondingly, a parliamentarian may parallel Russia with developing countries to ridicule the current state of 
affairs in Russia, which is evident in such expressions as "Please tell me more concretely, in which countries is there such term? Civilized countries, I am not talking about Africa or Latin America;” or, “Our Federation Council turns into Africa” (Duma, "Changes of the term of the President,” November 14, 2008: http://transcript.duma.gov.ru/node/450/). Likewise: "Believe me, African states and Latin American states have more women in their parliaments than Russia” (Duma, “Elections of state duma,” October 25, 2002: http://transcript.duma.gov.ru/node/1616/). Such references persist through the entire period, and we have illustrated it in this section by providing examples from different years.

The strength of this rhetorical strategy derives from the imagery of progress or modernization (Nisbet, 1980; Pollard, 1968). This imagery, culturally rooted in Enlightenment ideas and crude Darwinian evolutionism, centers on the sense of national states “modernizing” on a trajectory determined by the functional requirements of a "stage of development” (Alasuutari and Qadir, 2016). Such modernization discourse has had a central place in Russian social thought for the last two centuries (McDaniel, 1996), and the Soviet model of modernity enhanced the modernizing rationale with a "technocratic myth" (Gill, 2013: 246). Although important historical and sociological research offered a valuable cultural critique of such ideas (e.g. Baysha, 2015; Taylor, 1999), this imagery of society continues to exert its power, and is also utilized in other countries' debates.

The imagery of progress typically entails referencing Western countries in a positive tone, while in the same discourse developing nations are either ridiculed or referred to negatively. Developing countries are positively referred to mostly in cases when the Soviet Union is credited for investing resources in these countries, which enabled progress there. Either way, such modes of justifications are fed by an imagery of progress: modernizing nation-states arranged on a scale and quasi-temporal order. Of course, Western countries are 
sometimes referred to negatively as well, but this happens mostly in different debates when the imagery of competition is evoked as discussed in the next section.

The extent to which the modernizing imagery is rooted in the ways parliamentarians see the world, and more importantly in the ways they spontaneously utilize this imagery to convince the audience, is evident in the following dialogue between the two parliamentarians. Turkey often figures as a country that Russian parliamentarians are reluctant to set as an example for Russia:

Parlamentarian A: Not a single country in the world has 7-percent barrier. There are a couple of countries where there is a 6-percent barrier. 7-percent is found nowhere.

Parlamentarian B: As I remember, there is 7-percent in Turkey.

Parlamentarian A: Well, Turkey...I don’t think that we should equate to such countries as Turkey, in this question, in the question of following democratic norms. Everybody knows how they "follow" them [in Russian, presupposes skepticism] there in many directions (Duma, “Consumer protection,” October 10, 2002: http://transcript.duma.gov.ru/node/3881/).

The imagery of progress is also evoked in cases where Russia's actions are criticized in the West, for instance prosecution of "Pussy Riot" members after their famous performance in Moscow's Cathedral in 2012. Discussions around the bill on protection against offence of religious beliefs and feelings in 2013 took place in the first place as a reaction to this performance. Again, the Western countries are referred to positively as an example of legislation in this area. Notably, such positive referencing takes place during “developed Putinism”: 
The main regulations of this bill are little different from the regulations of the laws that now function in ten out of twelve EU countries, and I am talking about such democratic countries as Germany, Austria, Spain, Switzerland, Greece, Norway, Ireland, Italy, and Finland (Duma, “Countering offences of religious beliefs,” June 11, 2013: http://transcript.duma.gov.ru/node/3877/).

\section{"Keeping up with the Joneses": The imagery of competition}

According to Tsygankov (2015), the relationship between Russia on the one hand, and the United States and EU countries on the other, have been complex and dual-nature. He suggests that when Western states appear to challenge values that are commonly held in Russia to be distinct national markers — for instance spiritual freedom inspired by Eastern Christianity or a socially protective state defending its subjects—-Russia turns to a nationalistic and assertive foreign policy. Based on this and other research exploring microphenomenological political culture, it could be assumed that over the given period of time, the nature of references to other countries in the Russian duma would also change from the transitional years in the 1990s — when Western influences and financial aid were particularly prominent (Kotkin, 2001: 67)—-to the increasingly authoritarian and nationalistic Putin rule from 2000 (Neumann, 2008; Sakwa, 2013). This may well imply that Western countries would be referred to less and less positively in the analyzed debates. However, this is not the case. The Western countries, and especially the United States, are consistently figured as "normal” and "leading” countries through the entire analyzed period. The tone of such references is pragmatic and the United States is portrayed as a peer country, whose practices Russia would be "naturally" interested in considering for adaption, as in the following example: 
In all normal developed countries, in the United States, and European countries, fast and economic cars are made, but our Zhiguli are neither fast nor economic. And you suggest that we will keep on producing Zhigul?! I don’t understand that (Duma, “Central Bank,” December 7, 2010: http://transcript.duma.gov.ru/node/3302/).

We find similar examples throughout the 20 years' time span. On the one hand, Russian parliamentarians are rather similar to their colleagues in other countries, who also frequently utilize the US policies and legislation in their rhetorical strategies. On the other hand, these references are also well captured by the idiomatic expression "Keeping up with the Joneses,” denoting comparison to one's neighbor as a standard of wealth and social status. It is probably due to the relationship between the two superpowers during the Cold War that Russian parliamentarians see the United States as their most important neighbor and model, but also as a rival.

Of course, competing with Western capitalist countries for the image of a "good society" was a major driving engine of the Soviet project of modernity. The following quote illustrates how this spirit of competitiveness is present in current debates as well: "We have to overtake the West at least in this; we have not succeeded to overtake in terms of economy, but we have rich experiences regarding perfection of the border area” (Duma, May 16, 2002). The following quote, from a discussion among Russian parliamentarians on nuclear waste export, illustrates the multiple nature of references to the United States as a model to follow and as a competitor, including a conspiracy argument:

Parliamentarian A: ... when it comes to American interests, I deny that we lobby here any American interests, because actually Americans wait in line to export [their] 
nuclear waste to Russia. Those will lobby American interests who will vote for this bill now ...

Parliamentarian B: I declare quite officially that America is not going to export to us anything, to my knowledge. Moreover, it was mentioned that America with all the efforts tries to prevent us from approving these laws in order to narrow our market. It is connected to the fact that America wants to deprive us from our nuclear potential. Nuclear potential remains in the country only under the condition of the full fuelnuclear cycle. And ecologists want to deprive [us] from nuclear potential, those who were hired from the West on Western money, and others too who were hired.

Parliamentarian C: I say that the poignancy of the discussions here in this hall to a great extent reflects the poignancy on the world market. Today, it is obvious that major countries are interested in the market of use nuclear fuel, including the States, which now owns 70 percent of this market, and processes this fuel. European statesFrance, England, Belgium-also have shares in this market in big quantities. This is why Russia’s attempt to go to this market receives great resistance, and this is reflected in this hall (Duma, "Radioactive contaminated territories,” December 21, 2000: http://transcript.duma.gov.ru/node/2040/).

Such discourse illustrates another powerful imagery of the social world at work, one that relates to a view of the world as divided into camps or blocs that pursue their own interests and hence fight or compete against each other. The spontaneous and naturalized ways in which Russian parliamentarians evoke this imagery with regard to USA is precisely due to the fact that the so-called East-West or communist-capitalist division led by the Soviet 
Union and the United States as superpowers was a popular way to divide the world into two competing blocs. For Russian parliamentarians, the USA is a self-evident peer country that Russia can be compared to, and with which it competes. This imagery is at the heart of modern international culture, according to which the nation-state is perceived as a largely homogenous, largely distinct, rational actor in an anarchic competition amongst other nationstates for resources and influence. The extract above is also an illustration of how "the West" is referenced negatively. This typically happens when the imagery of competition is evoked. This is in contrast with the modes of justifications that draw on the imagery of progress, when the same Western countries are referred to positively.

A key feature of this imagery of competing blocs is to identify or construct national uniqueness of specific cultural values. Building such a picture is an obvious strategy when speakers assume that their audiences perceive the world as an anarchic competition amongst nation-states, and that they can portray certain features as giving a moral or competitive edge. For instance:

It is well known that national features of the people of Russia are compassion and kindness ... One Russian family was refused to adopt a sick child. She [the mother] asks the parliamentarian D. "The motivation was that the child was sick and that he is going to be adopted by a family from America. A question arises: why can an American family take care of the child, but the Russian family was refused that? I think that honor and dignity of the Russian citizen were offended" (Duma, "Family code,” December 25, 1997: http://transcript.duma.gov.ru/node/2641/).

\section{Discussion: Mesophenomenology of world culture}


In this paper, we attempted to shed light on how similar or different Russia is from other countries in parliamentary debates. Staying in between macrophenomenological discussions on isomorphism by WST scholars on one hand, and microphenomenological analyses of political culture on the other, we examined political discourse in a quintessential site of world culture: the Russian parliament. As in parliamentary talk in other countries, developed Western nations are referred to positively in the Russian Duma when the imagery of progress is dominant in a debate. In contrast, when the imagery of competition is evoked, the references to the Western countries become negative, and are often made in a conspiracy fashion. However, both these imageries are in fact "scripts” of world culture. Even if they may be evoked in somewhat different times or in somewhat different policy sectors from other countries, they demonstrate that Russia is part of political world culture.

From this discursive perspective, we find remarkable similarities between Russia and other analyzed countries in parliamentarians drawing on international references to justify new legislation. This sort of reference is extremely important since it links Russia inevitably to the world polity despite the rhetoric of cultural uniqueness. Indeed, the rhetoric of uniqueness is, itself, common in other countries, especially in the USA. It is, thus, very significant that the same six categories of referencing the international community are to be found in Russia as elsewhere. There are no exclusive categories, nor are there categories that exist elsewhere but are not at all present in Russian parliamentary talk.

Similarly, when we investigate the patterns of talk by which Russian parliamentarians try to convince others of their point of view, we find that they assume that their audiences believe in the same type of the social world that politicians in other countries do. They cast their arguments in terms of universal progress, or in terms of competing blocs, obviously because they believe their audience will be convinced by such meta-narrative imageries. Whether or not speakers genuinely and privately believe in such narratives is a different 
question. What is relevant is that their political talk evokes the prevalence of such imageries. Once more, we find no significant differences between the period before Putin’s ascendency and the period of his consolidation of authority. The evidence of similar imageries to what are deployed in the other parliaments shows how close in fact Russian parliamentary discourse matches parliamentary debates elsewhere, including in the USA.

By stressing the same institutional infrastructures and globally shared ideals and principles, we do not intend to argue that Russia is already or is becoming identical with Western liberal democracies. Much research has rightly pointed out that such a transition has not taken place, or that the changes witnessed in the past decades have taken unexpected directions. Yet the similarity in form of parliamentarian talk, as evident in references to the international community, ties Russia to the world society. In this respect, our study fills a crucial gap in WST studies that have largely ignored Russia as part of the single world polity.

However, the complexity of our findings suggests that the view that interdependent decision-making leads to growing isomorphism is too narrow to capture the phenomenon. The overall macrophenomenological perspective of the globe has much evidence to support it, including for Russia. But it doesn’t explain how this comes about from individual actions by local decision-makers, given the specificity of Russian microphenomenological political culture (and similarly unique political cultures everywhere). Our meso-level analysis bridges this gap by showing that Russian parliamentarians, just like in other countries, keep a keen eye on what other countries are up to in their policymaking, and use that evidence in support for their argument. Such a meso-level discursive view on institutional politics lends credence to the concept of synchronization of national policies. From this perspective it is also possible to understand that the socialist bloc was another version of the political trends of that era and, as a member of the globally synchronized network of nation-states, it also responds to the same signals and fashions that run through and across that network. 


\section{Notes}

${ }^{1}$ In the Soviet Union there certainly were many phenomena that can be regarded as hypocritical showcasing and image management, for instance elections with only one party that had, moreover, prepared the list of people to be elected. However, such arrangements were rationalized and justified by declaring them "dictatorship of the proletariat," represented by the party. It is not a very common justification, but yet one that shows how local political struggles are rhetorically portrayed as being part of legitimate world culture.

${ }^{2}$ We also find a third imagery, that of power organized as a hierarchy. However, that imagery is more difficult to track directly than these two, and requires further close reading of the parliamentary debates. We propose to follow up on this imagery in a cross-national comparative research later. 


\section{References}

Alasuutari P. (2016) The Synchronization of National Policies: Ethnography of the Global Tribe of Moderns, London: Routledge.

Alasuutari P and Qadir A. (2016) Imageries of the social world in epistemic governance. International Sociology 31: 633-652.

Alasuutari P and Qadir A. (2014a) Epistemic governance: An approach to the politics of policy-making. European Journal of Cultural and Political Sociology 1: 67-84.

Alasuutari P and Qadir A (eds). (2014b) National Policy-Making: Domestication of Global Trends, London: Routledge.

Anderson B. (1991) Imagined Communities: Reflections on the Origin and Spread of Nationalism, London: Verso.

Baysha O. (2015) Ukrainian Euromaidan: The Exclusion of Otherness in the Name of Progress. European Journal of Cultural Studies 18: 3-18.

Billig M. (1996) Arguing and Thinking: A Rhetorical Approach to Social Psychology, Cambridge: Cambridge University Press.

Bockman J. (2007) The Origins of Neoliberalism between Soviet Socialism and Western Capitalism: "A Galaxy without Borders". Theory and Society 36: 343-371.

Bradley K and Ramirez FO. (1996) World polity promotion of gender parity: Women's share of higher education, 1965-1985. Research in Sociology of Education and Socialization 11: 63-91.

Bromley P and Powell WW. (2012) From Smoke and Mirrors to Walking the Talk: Decoupling in the Contemporary World. Academy of Management Annals 6: 483530. 
Brown RH. (1989) A Poetic for Sociology: Toward a Logic of Discovery for the Human Sciences, Cambridge, UK: Cambridge University Press.

Burawoy M and Verdery K. (1999) Uncertain Transition: Ethnographies of Change in the Postsocialist World. Lanham, London: Rowman \& Littlefield.

Fairclough I and Fairclough N. (2013) Political Discourse Analysis: A Method for Advanced Students, London: Routledge.

Fairclough N. (2003) Analysing Discourse: Textual Analysis for Social Research, London: Routledge.

Ferguson J. (1999) Expectations of Modernity: Myths and Meanings of Urban Life on the Zambian Copperbelt, Berkeley: University of California Press.

Gill G. (2013) Political symbolism and the fall of the USSR. Europe-Asia Studies 65: 244263.

Hann C, Humphrey C and Verdery K. (2002) (eds) Postsocialism: Ideals, Ideologies and Practices. London: Routledge, 1-28.

Harvey D. (2005) A Brief History of Neoliberalism, Oxford ; New York: Oxford University Press.

Hedin A. (2016) Cold war isomorphism: communist regimes and the West European model of worker participation. European Journal of Cultural and Political Sociology 3: 201242.

Humphrey C. (2002) The Unmaking of Soviet Life: Everyday Economies after Socialism, Ithaca: Cornell University Press.

Kangas A and Salmenniemi S. (2016) Decolonizing knowledge: neoliberalism beyond the three worlds. Distinktion: Journal of Social Theory 17: 210-227

Kotkin S. (2001) Armageddion Averted: The Soviet Collapse, 1970-2000, Oxford: Oxford University Press. 
Lyytikäinen L. (2016) Performing Political Opposition in Russia: The Case of the Youth Group Oborona, London: Routledge.

MacIntyre AC. (1981) After Virtue: A Study in Moral Theory, Notre Dame: University of Notre Dame Press.

McDaniel T. (1996) The agony of the Russian idea, Princeton, N.J. ; Chichester: Princeton University Press.

Meyer JW. (2010) World Society, Institutional Theories, and the Actor. Annual Review of Sociology 36: 1-20.

Meyer JW, Boli J, Thomas GM, et al. (1997) World Society and the Nation-State. American Journal of Sociology 103: 144-181.

Meyer JW, Krücken G and Drori GS (eds). (2009) World Society: The Writings of John W. Meyer, Oxford: Oxford University Press.

Morozov V. (2013) Subaltern empire? Problems of Post-Communism 60: 16-28.

Neumann IB. (2008) Russia as a great power, 1815-2007. Journal of International Relations and Development 11: 128-151.

Nisbet R. (1980) History of the Idea of Progress, London: Transaction.

Perelman C. (1982) The Realm of Rhetoric, Notre Dame: University of Notre Dame Press. Polanyi K. (1957) The Great Transformation: The Political and Economic Origins of our Time, Boston, MA: Beacon Press.

Pollard S. (1968) The Idea of Progress: History and Society, London: Watts.

Potter J. (1996) Representing Reality: Discourse, Rhetoric and Social Construction, Thousand Oaks, CA: Sage.

Qadir A. (2016) Editorial: Through an iron cage, darkly. European Journal of Cultural and Political Sociology 3: 141-151. 
Rogers D. (2010) Postsocialisms unbound: connections, critiques, comparisons. Slavic Review 69.

Sakwa R. (2008) Russian Politics and Society, London: Routledge.

Sakwa R. (2013) Developed Putinism: Change without development. Russian Analytical Digest: 2-4.

Salmenniemi S. (2008) Democratization and Gender in Contemporary Russia, London: Taylor\&Francis.

Stivachtis YA. (2015) Liberal democracy, market economy, and international conduct as standards of ‘civilization' in contemporary international society: The case of Russia's entry into the 'community of civilized states'. Journal of Eurasian Studies 6: 130142.

Taylor C. (1999) Two Theories of Modernity. Public Culture 11: 153-174.

Thomas GM. (2009) World Polity, World Culture, World Society. International Political Sociology 3: 115-119.

Trichur G. (2005) The new imperial conjuncture and alternative futures for 21st-century global political economy. Globalizations 2: 164-181.

Tsygankov AP. (2015) Vladimir Putin's last stand: The sources of Russia's Ukraine policy. Post-Soviet Affairs 31: 279-303.

Tsygankov AP and Tsygankov PA. (2007) A sociology of dependence in international relations theory: A case of Russian liberal IR. International Political Sociology 1: 307-324.

Watson A. (1992) The Evolution of International Society: A Comparative Historical Analysis, London: Routledge.

Whitefield S (ed) (2005) Political Culture and Post-Communism, Basingstoke: Palgrave Macmillan. 
Wood LA and Kroger RO. (2000) Doing Discourse Analysis: Methods for Studying Action in Talk and Text, Thousand Oaks: Sage Publications.

\section{Author biographies}

Dr. Tatiana Tiaynen-Qadir obtained her PhD from the University of Tampere and is now postdoctoral researcher at the University of Eastern Finland. Her current research interests include transnational anthropology and sociology, women’s ageing, Russian studies, therapy cultures and vernacular religion. She has published two monographs, as well as articles in academic journals and edited volumes in Russian, Finnish and English languages.

Dr. Ali Qadir is Associate Professor, New Social Research at the University of Tampere, and Docent in Ethnic Relations at the University of Helsinki. His research interests are global and transnational sociology, as well as sociology of religion, and he has published widely in international articles and as editor of scientific volumes. He presently holds an Academy of Finland research grant on "Morality in politics."

Dr. Pertti Alasuutari is Academy Professor at the University of Tampere, Faculty of Social Sciences. His research interests include global and transnational phenomena, media, social theory, and social research methodology. His monographs include The Synchronization of National Policies (Routledge 2016), Social Theory and Human Reality (Sage 2004), Rethinking the Media Audience (Sage 1999), An Invitation to Social Research (Sage 1998), and Researching Culture: Qualitative Method and Cultural Studies (Sage 1995). He has a total of 176 scientific publications, including 46 peer-reviewed articles and nine books in English. 